\title{
Blood Pressure Monitoring and Analysis as Android Application
}

\author{
D.Jeyapriya, S.R.Sri Vidhya, R.Velvizhi
}

\begin{abstract}
Hypertension is a perilous condition, however easy to analyze by estimating the pulse. Cell phones are omnipresent, so a pulse gadget includingjust the advanced cell can make conclusion normally accessible without the need to obtain access to a unique pulse gadget. This paper surveys late advances in pulse estimations, particularly with center around those actualized for advanced cells. At last, future conceivable headings are specified. Watchwords-advanced mobile phone, pulse, therapeutic gadget, sensor Presentation (a) Bluetooth empowered ECG sensor. (b) Microphone-based computerized Source: Clockwise.de stethoscope. Source: [7]. Hypertension is a risky condition, which can prompt cardiovascular disceases, most generally known is stroke in the heart.
\end{abstract}

Index Terms: sensors,signals,diagonise

\section{INTRODUCTION}

Positioning is In 1990, India saw 1.3 million passings from stroke, straightforwardly identified with hypertension, and research proposes this will just increment in the coming years [1]. Diagnosing hypertension in the populace is the first and generally vital advance so as to diminish the danger of hypertension-related illnesses. To analyze hypertension is generally straightforward, as it requires essentially information of a man's circulatory strain (see Tab. I), in this manner relies upon the accessibility of a gadget to measure the pulse. Pulse classification Systolic $(\mathrm{mmHg})$ Diastolic (mmHg) Typical < 120 and < 80 Prehypertension 120139 or 8089 Hypertension 1401599099 (Hypertension) Stage 1 or Hypertension (Hypertension) Stage $2>160$ or $>100$ Hypertensive Crisis > 180 or > 110 TABLE I: Blood weight classes. Source: American Heart Association Pulse is ordinarily recorded as two numbers, composed as a proportion this way: Systolic/Diastolic. The best number (systolic), which is additionally the higher of the two numbers, measures the weight in the supply routes when the heart pulsates (when the heart muscle contracts). The base number (diastolic), which is likewise the lower of the two numbers, measures the weight in the courses between heartbeats (when the heart muscle is resting amongst

\section{Revised Manuscript Received on July 22, 2019.}

R.Velvizhi, Department of Computer Science and Engineering, Bharath Institute of Higher education and research, Chennai, India

D.Jeyapriya,, Department of Computer Science and Engineering, Bharath Institute of Higher education and research, Chennai, India

S.R.Srividhya, Department of Computer Science and Engineering, Bharath Institute of Higher education and research, Chennai, India pulsates and refilling with blood). Normal circulatory strain techniques are: 1) the auscultatory strategy utilized as a part of a clinical setting where a stethoscope and a sphygmomanometer are utilized to pressurize the upper arm, and tune in for blood stream (supposed Korotkoff sounds); 2) the oscillometric strategy, regularly utilized as a part of home, takes after same guideline, however utilizes electronic investigation of the blood stream rather than human tuning in. Both the basic techniques are sleeve based, which means they require swelling and weight connected. This is regularly exasperating the patient, prompting an overestimation of circulatory strain. Subsequently, sleeve less techniques are looked for straightforwardness and plausibility of continous observing. Estimation of circulatory strain has for quite some time been a dynamic field of research. As of late techniques have been produced with center around computerized sensors, flag preparing and machine learning. The rest of the paper is sorted out as takes after: Area II plate which sensors are utilized together with their individual flag preparing techniques. Area III disk the techniques utilized for delivering BP yield from accessible sensor inputs. At long last, in Section IV, future changes are specified, what's more, the paper is finished up.

\section{MATERIALS AND METHODOLOGY}

Watching the patient requires input, either indicated by the understanding herself, or by the utilization of sensors. Customary sensors for example, ECG and computerized stethoscope (see Fig. 1) have been utilized together with advanced mobile phones for estimating BP [2]- [6]. For the advanced mobile phone based BP gadget, a few sensors have been proposed, which are accessible in a large portion of the present cell phones:Accelerometer, detects development of the telephone. Amplifier, sound sensor.Touch-screen, detects finger-development and finger-weight on the screen. Camera, visual sensor. Accelerometer as heart-beat sensor: The accelerometer gives the advanced mobile phone information about movement, such as quickening powers or turn. In [8], the accelerometer was exhibited to have the capacity to gauge the heart-beat at the heart, by tying an iPhone to the patient's chest. The accelerometer gives data about quickening along $\mathrm{X}, \mathrm{Y}$ and $\mathrm{Z}$ pivot, and relying upon the situation of the patient, the heart-beat must be recognized along the right hub, or, perhaps a mix thereof. [8] demonstrated that the exactness of identifying heart-beat was in $[0: 76 ; 0: 98]$ when the patient was not moving. While moving (e.g. strolling) the flag clamor from venturing eclipsed the heart-beat. Camera as photoplethysmography sensor: The camera sensor can be utilized

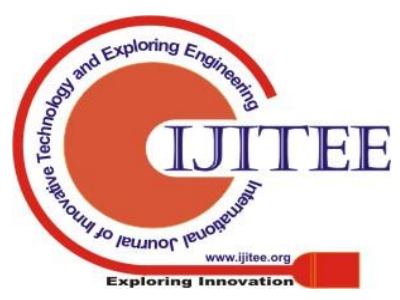


as a photoplethysmography (PPG) sensor. PPG is detecting change in the oxidation of a body-part, as an impact of the beat wave. PPG with the advanced cell is based on the glimmer LED and the camera. The LED enlightens the fingertip, giving a clearer perspective of the oxidation, and the camera as sensor, see Fig. 2. The adjustment in brightening in the camera is the flag SP (t), as demonstrated as follows: where the determination of the caught picture is $h$ $\mathrm{w}, \operatorname{Iij}(\mathrm{t})$ is the pixel $\mathrm{I} ; \mathrm{j}$ in the camera picture at $\mathrm{t}$ and green is a capacity to extricate the green shading force from the pixel. PPG is an ordinarily utilized sensor [3]- [5], [9]- [13] due to its strength towards meddle from different sensors, be that as it may, advanced mobile phones more often than not contains just a single such sensor (Driven isn't accessible for front camera). Touch screen as a strain sensor: The touch screen in PDAs is ordinarily utilized as a navigational apparatus, by to estimating the situation of the finger on the screen. Be that as it may, they additionally permit to gauge variety in weight. This has been utilized as a part of Fig. 5(b) where the finger is set over the screen. At the point when the beat wave achieves the finger, it gives a slight change in weight, which is the yield flag of this sensor. Microphone as un-opened up stethoscope: The amplifier in the advanced mobile phone can be utilized as a stethoscope. As with an ordinary stethoscope, the black out heart sounds are opened up. As the amplifier is inclined to outside clamor, this requires hush what's more, flag sifting to separate the heart sound. Fig. 5(a) employments the receiver to gauge beat wave at the heart.

A. Handling sensor signals Sensor signals are normally loud. For instance, an audiowaveform from a mouthpiece encodes a few frequencies from encompassing clamor, and a plethysmographic sensor gives a subtlely unique enlightenment for each edge, due to changed light conditions in the room of the patient. The techniques for estimating circulatory strain need to know the beat wave, and handling the crude flag is done all together to get a smooth bend, where the beat wave can be certainly identified. The precision for all strategies is inside $[0: 72 ; 1: 0]$. The most precise strategies depend on outside sensors [3], [20], be that as it may, elective techniques considering just a solitary PPG sensor alongside logical highlights are additionally indicating great precision [9], [11] under perfect conditions

\section{RESULTS AND DISCUSSIONS}

In this segment the precision of current techniques is assessed, in light of which future bearings are examined, and the paper is closed. A. Precision The new BP estimation gadgets indicate promising announced precision in estimating esteems predictable with conventional BP estimation, (for example, a sphygmomanometer or a sleeve based oscillatory gadget). For the strategies said inthis paper, the precision has been gathered into the outline. Future workWhile the announced exactnesses are as of now very great, there is still opportunity to get better under not as much as perfect conditions. Adding more sensors permits to quantify the heart-beat and finger beat all the more definitely. In the advanced mobile phone based gadget it is however not generally an answer, as the sensor's signs may cover. Human $\mathrm{PC} /$ gadget interface All circulatory strain gadgets show just a similar three yields: 1) beat; 2) diastolic weight; 3) systolic weight (see two illustration Android based applications in Fig. 5). For the medicinal services proficient, this data is fundamental and in light of the preparation, a legitimate determination can be made.

\section{CONCLUSIONS}

For the persistent the story might be unique, recollecting the points of confinement for a typical condition, or, when a visit to the specialist is inescapable, may not be conceivable. Another fascinating heading in human PC/gadget association is that a few techniques may offer persistent estimation of BP. This could give space for examine into techniques for cautioning the patient (or specialist), should a given BP occasion happen. E. Conclusion Taking everything into account, this paper has presented the issue of hypertension, and explored current patterns in advanced mobile phone based circulatory strain gadgets to make hypertension observing simpler. Utilized info sensors have been portrayed and techniques inspected; observed to be of good exactness to profit the hyperten-sion group. At long last, conceivable future bearings have been given.

\section{REFERENCES}

[1] Kumarave A., Rangarajan K.,Algorithm for automaton specification for exploring dynamic labyrinths,Indian Journal of Science and Technology,V-6,I-SUPPL5,PP-4554-4559,Y-2013

[2] P. Kavitha, S. Prabakaran "A Novel Hybrid Segmentation Method with Particle Swarm Optimization and Fuzzy C-Mean Based On Partitioning the Image for Detecting Lung Cancer" International Journal of Engineering and Advanced Technology (IJEAT) ISSN 2249-8958, Volume-8 Issue-5, June 2019

[3] Kumaravel A., Meetei O.N.,An application of non-uniform cellular automata for efficient cryptography,2013 IEEE Conference on Information and Communication Technologies, ICT 2013,V-,I-,PP-1200-1205,Y-2013

[4] Kumarave A., Rangarajan K.,Routing alogrithm over semi-regular tessellations,2013 IEEE Conference on Information and Communication Technologies,

2013,V-,I-,PP-1180-1184,Y-2013

[5] P. Kavitha, S. Prabakaran "Designing a Feature Vector for Statistical Texture Analysis of Brain Tumor" International Journal of Engineering and Advanced Technology (IJEAT) ISSN: 2249-8958, Volume-8 Issue-5, June 2019

[6] Dutta P., Kumaravel A.,A novel approach to trust based identification of leaders in social networks,Indian Journal of Science and Technology,V-9,I-10,PP--,Y-2016

[7] Kumaravel A., Dutta P.,Application of Pca for context selection for collaborative filtering,Middle - East Journal of Scientific Research,V-20,I-1,PP-88-93,Y-2014

[8] Kumaravel A., Rangarajan K.,Constructing an automaton for exploring dynamic labyrinths,2012 International Conference on Radar, Communication and Computing, ICRCC 2012,V-,I-,PP-161-165,Y-2012

[9] P. Kavitha, S. Prabakaran "Adaptive Bilateral Filter for Multi-Resolution in Brain Tumor Recognition" International Journal of Innovative Technology and Exploring Engineering (IJITEE) ISSN: 2278-3075, Volume-8 Issue-8 June, 2019

[10] Kumaravel A.,Comparison of two multi-classification approaches for detecting network attacks, World Applied Sciences Journal,V-27,I-11,PP-1461-1465,Y-2013

[11] Tariq J., Kumaravel A.,Construction of cellular automata over hexagonal and triangular tessellations for path planning of multi-robots,2016 IEEE International Conference on Computational Intelligence and Computing Research, ICCIC 2016,V-,I-,PP--,Y-2017

[12] Sudha M., Kumaravel A.,Analysis and measurement of wave guides using poisson method,Indonesian Journal of

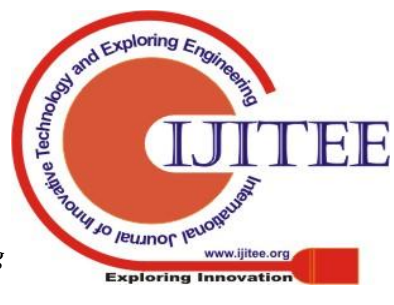


Electrical

Engineering

Science,V-8,I-2,PP-546-548,Y-2017

[13] Ayyappan G., Nalini C., Kumaravel A.,Various approaches of knowledge transfer in academic social network,International Journal of Engineering and Technology,V-,I-,PP-2791-2794,Y-2017

[14] Kaliyamurthie, K.P., Sivaraman, K., Ramesh, S. Imposing patien data privacy in wireless medical sensor networks through homomorphic cryptosystems 2016, Journal of Chemical and Pharmaceutical Sciences 92.

[15] Kaliyamurthie, K.P., Balasubramanian, P.C. An approach to multi secure to historical malformed documents using integer ripple transfiguration 2016 Journal of Chemical and Pharmaceutical Sciences 92.

[16] A.Sangeetha,C.Nalini,"Semantic Ranking based on keywords extractions in the web", International Journal of Engineering \& Technology, 7 (2.6) (2018) 290-292

[17] S.V.GayathiriDevi,C.Nalini,N.Kumar,"An efficient software verification using multi-layered software verification too "International Journal of Engineering \& Technology, 7(2.21)2018 454-457

[18] C.Nalini,ShwtambariKharabe,"A Comparative Study On Differen Techniques Used For Finger - Vein Authentication", Internationa Journal Of Pure And Applied Mathematics, Volume 116 No. 82017 327-333, Issn: 1314-3395

[19] M.S. Vivekanandan and Dr. C. Rajabhushanam, "Enabling Privacy Protection and Content Assurance in Geo-Social Networks", International Journal of Innovative Research in Management, Engineering and Technology, Vol 3, Issue 4, pp. 49-55, April 2018.

[20] Dr. C. Rajabhushanam, V. Karthik, and G. Vivek, "Elasticity in Cloud Computing", International Journal of Innovative Research in Management, Engineering and Technology, Vol 3, Issue 4, pp. 104-111, April 2018.

[21] K. Rangaswamy and Dr. C. Rajabhushanamc, "CCN-Based Congestion Control Mechanism In Dynamic Networks", Internationa Journal of Innovative Research in Management, Engineering and Technology, Vol 3, Issue 4, pp. 117-119, April 2018.

[22] Kavitha, R., Nedunchelian, R., "Domain-specific Search engine optimization using healthcare ontology and a neural network backpropagation approach", 2017, Research Journal of Biotechnology, Special Issue 2:157-166

[23] Kavitha, G., Kavitha, R., "An analysis to improve throughput of high-power hubs in mobile ad hoc network" , 2016, Journal of Chemical and Pharmaceutical Sciences, Vol-9, Issue-2: 361-363

[24] Kavitha, G., Kavitha, R., "Dipping interference to supplement throughput in MANET", 2016, Journal of Chemical and Pharmaceutical Sciences, Vol-9, Issue-2: 357-360

[25] Michael, G., Chandrasekar, A.,'Leader election based malicious detection and response system in MANET using mechanism design approach", Journal of Chemical and Pharmaceutical Sciences(JCPS) Volume 9 Issue 2, April - June 2016

[26] Michael, G., Chandrasekar, A.,"Modeling of detection of camouflaging worm using epidemic dynamic model and power spectral density", Journal of Chemical and Pharmaceutical Sciences(JCPS) Volume 9 Issue 2, April - June 2016

[27] Pothumani, S., Sriram, M., Sridhar, J., Arul Selvan, G., Secure mobile agents communication on intranet,Journal of Chemical and Pharmaceutical Sciences, volume 9, Issue 3, Pg No S32-S35, 2016

[28] Pothumani, S., Sriram, M., Sridhar , Various schemes for database encryption-a survey, Journal of Chemical and Pharmaceutical Sciences, volume 9, Issue 3, Pg NoS103-S106, 2016

[29] Pothumani, S., Sriram, M., Sridhar, A novel economic framework for cloud and grid computing, Journal of Chemical and Pharmaceutical Sciences, volume 9, Issue 3, Pg No S29-S31, 2016

[30] Priya, N., Sridhar, J., Sriram, M. "Ecommerce Transaction Security Challenges and Prevention Methods- New Approach” 2016 ,Journa of Chemical and Pharmaceutical Sciences, JCPS Volume 9 Issue 3.page no:S66-S68

[31] Priya, N.,Sridhar,J.,Sriram, M."Vehicular cloud computing security issues and solutions" Journal of Chemical and Pharmaceutical Sciences(JCPS) Volume 9 Issue 2, April - June 2016

[32] Priya, N., Sridhar, J., Sriram, M. "Mobile large data storage security in cloud computing environment-a new approach" JCPS Volume 9 Issue 2. April - June 2016

[33] Anuradha.C, Khanna.V, "Improving network performance and security in WSN using decentralized hypothesis testing "Journal of Chemical and Pharmaceutical Sciences(JCPS) Volume 9 Issue 2, April - June 2016

[34] Anuradha.C, Khanna.V, "A novel gsm based control for e-devices" Journal of Chemical and Pharmaceutical Sciences(JCPS) Volume 9 Issue 2, April - June 2016 .
[35] Anuradha.C, Khanna.V, "Secured privacy preserving sharing and data integration in mobile web environments " Journal of Chemical and Pharmaceutical Sciences(JCPS) Volume 9 Issue 2, April - June 2016

[36] Sundarraj, B., Kaliyamurthie, K.P. Social network analysis for decisive the ultimate classification from the ensemble to boost accuracy rates 2016 International Journal of Pharmacy and Technology 8

[37] Sundarraj, B., Kaliyamurthie, K.P. A content-based spam filtering approach victimisation artificial neural networks 2016 International Journal of Pharmacy and Technology $8 \quad 3$.

[38] Sundarraj, B., Kaliyamurthie, K.P. Remote sensing imaging for satellite image segmentation 2016 International Journal of Pharmacy and Technology 83 .

[39] Sivaraman, K., Senthil, M. Intuitive driver proxy control using artificial intelligence 2016 International Journal of Pharmacy and Technology 84.

[40] Sivaraman, K., Kaliyamurthie, K.P. Cloud computing in mobile technology 2016 Journal of Chemical and Pharmaceutical Sciences 92.

[41] Sivaraman, K., Khanna, V. Implementation of an extension for browser to detect vulnerable elements on web pages and avoid click jacking 2016 Journal of Chemical and Pharmaceutical Sciences 92.

\section{AUTHORS PROFILE}

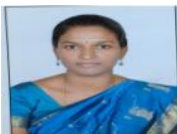

D.Jeyapriya, Assistant Professor, Department of Computer Science \& Engineering, Bharath Institute of Higher Education and Research, Chennai, India

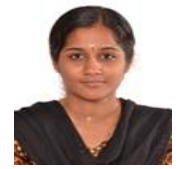

SR.Srividhya, Assistant Professor, Department of Computer Science \& Engineering, Bharath Institute of Higher Education and Research, Chennai

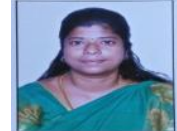

R.Velvizhi, Assistant Professor, Department of Computer Science \& Engineering, Bharath Institute of Higher Education and Research, Chennai 